\title{
Factors Influencing Innovative Behaviour of Teachers in Secondary Schools in the North East of Nigeria
}

\author{
Faiza Abubakar Bawuro ${ }^{1,2}$, Ibrahim Danjuma ${ }^{2}$, Helavalada Wajiga ${ }^{2}$ \\ ${ }^{1}$ Universiti Tun Hussein Onn Malaysia \\ 101 Parit Raja, Batu Pahat, Johor, 86400, Malaysia \\ ${ }^{2}$ Modibbo Adama University of Technology, Yola \\ P. M. B. 2076, Yola, Adamawa State, Nigeria
}

DOI: $10.22178 /$ pos.32-9

LCC Subject Category:

LB1705-2286

Received 10.02.2018

Accepted 15.03.2018

Published online 24.03.2018

Corresponding Author:

Faiza Abubakar Bawuro,

faizabawuro@gmail.com

(C) 2018 The Authors. This article is licensed under a Creative Commons Attribution 4.0 License @) (1)
Abstract. Innovative behaviour (IB) refers to the process of developing, generating, applying or promoting new ideas by employees to increase job performance. Today, the rapid social and technological changes in our environment highlight the significance of IB of employees and especially for teachers. Thus, this paper aimed to develop a conceptual framework of factors influencing innovative behaviour of teachers in secondary schools. The research was explored through critical related literature analysis. Findings were presented in form of descriptive analysis, which shows that workplace happiness (WP), organisational climate (OC), affective commitment (AF) and transformational leadership (TFL) play a direct role in affecting innovative behaviour. The paper concludes that WP, $\mathrm{OC}, \mathrm{AF}$ and $\mathrm{TL}$ have a positive impact in creating the essential conditions to encourage teachers to show IB in schools.

Keywords: innovative behaviour; workplace happiness; organizational climate; affective commitment; transformational leadership; teachers.

\section{INTRODUCTION}

Teachers play a significant role in creating and maintaining effective learning to face the challenges of teaching in the 21st century. The rapid social, economic and technological changes in our society made it impossible to manage educational institutes [1]. Thus, efficient knowledge and teacher's innovative behaviour are crucial for providing high quality education [2].

Innovative behaviour is defined as the deliberate action to develop or produce idea to enhance role performance [3]. While Y. Kheng and R. Mahmood [4] describe innovative behaviour as the process of introducing new ideas and carrying it to its final stage of implementation. Hence, innovative teaching is important for all teachers to meet the present and future educational needs of today [5]. School management must integrate all creative intellectual activities, technical skills, leadership skills, generate change and support various forms of activities that would allow the schools to survive in the modern climate to secure their future [6]. However, what is more significant than innovation is how the innovative ideas are developed [7]. Thus, J. de Jong and D. Hartog [8] proposed four components model of innovative behaviour to provide an explanation on how individual's innovate and implement new ideas. These components include: the opportunity exploration, idea generation, championing or supporting the idea and implementation. C. Binnewies and M. Gromer [9] highlight that it is significant to note that team work and cooperation enhance innovation, it is difficult for innovation to be forged by an individual alone.

Scholars have paid attention to the research of organisational innovation and individual innovation $[10,11]$. As a result, issues affecting innovative work behaviour of employees have been 
widely investigated $[6,12,13]$. The findings from literature reveal that issues such as workplace happiness, organisational climate, affective commitment and leadership style are some of the identified factors affecting innovative behaviour of individuals at work [14, 15, 16]. However, most of these research studies on innovative behaviour (IB) are mainly carried out in first world countries and focused on service, manufacturing and industrial sectors [17]. M. Thurlings, A. Evers, M. Vermeulen [6] argue that research studies on IB have not yet received the level of attention in third world countries. It is against this phenomenon that this paper proposed to fill a knowledge gap related to IB in educational institutes, whose duty is designed to provide valuable and useful knowledge to students. Hence, this paper aimed to investigate factors influencing IB of teachers in secondary schools. It is believed that this study will provide relevant information on IB that would help the government to develop an effective educational reform to benefit its citizens.

\section{Teachers Innovative Behaviour}

IB is an intentional or deliberate behaviour of individuals to develop or apply new ideas to enhance role performance [18]. While Y. Kheng and R. Mahmood [4] define IB as the intentional efforts to gain amazing rewards. However, O. Janssen [19] argues that individual behaviour should emphasise IB and should not be limited to additional role in reward system. As a result, the combination of views formed three components of IB, which includes the following: (1) generation of idea (2) idea promotion (3) realisation of idea in teaching and learning.

Ideation means the formulation of new ideas in teaching and learning. While promotional ideas are associated to situations where teachers are bound by the obligations to generate new ideas for teaching and learning [20]. Thus, teachers need basic knowledge and skills or the appropriate method to promote ideas that can be utilized designing and delivering classes [21]. For example, by finding allies or organisers that can support or influence the implementation of new teaching methods or updated curriculum in schools. Lastly, realization refers to the process of innovation to realize initial idea [20]. Therefore, S. Scott, R. Bruce [22] suggest follow-up process also known as model of education, where ideas can exist in form of teaching experience that constitutes an additional role in the behaviour of the work, especially in teaching and learning.

Therefore, C. Kivunja [23] defines innovative teaching as the ability of the teachers to engage students in the classroom, to improve students' ability to learn, to identify and address the different needs of students by applying strategies. Also, it helps the teachers to identify their creativity in the learning process. M. Buxton, J. Phillippi, M. Collins [24] confirm that teacher's innovation is important for both the teacher and student in the learning process. It improves teaching methods and ensures attention management of students.

\section{Workplace happiness}

The concept 'happiness' has been a subject of debate in recent years [25]. It refers to the feeling or experience of satisfaction, positive wellbeing, sense of joy combined with meaningful work [26]. Evidence show that the presence of happiness at work encourages positive outcomes [5, $27,28,29,30]$. Thus, happiness is a multidimensional construct that comprises of many components such as satisfaction, autonomy, work integration and aspiration [31]. A. Kaya [32] believes that happiness at workplace often has positive impact rather than negative impact on people. L. Straume, J. Vittersø [33] identified that there are two approaches of happiness namely: hedonic and eudaimonic approach. Hedonic approach focuses on pleasures of the mind and body by avoiding pain. While eudaimonic approach is a deeper level of perceived happiness that exist through involvement or doing something meaningful and noble that generate progress. Literature reveals a positive connection of happiness at the workplace on creativity [34]; self-efficacy [35]; job satisfaction [26]; emotional stability [36]; intention to quit [37].

A. Abdullah, Y.-L. Ling [5] found that leaders can improve workplace happiness to increase the level of IB among employees. This means that leaders can affect the mood of their followers to ensure innovativeness. According to E.Tee, N. Ashkanasy, N. Paulsen [38], positive mood state of a leader can influence the followers to experience the same positive mood. This is because a leader's mood can provide a better or conducive environment to influence or control the interaction of resources [39]. Thus, teacher's 
emotional state or mood can affect teaching and learning [40]. P. Garner [41] explains that since happiness is an element of mood that encourages a person to feel, think or act towards achievement of goals, a positive mood of a teacher can affect co-workers and students. This positive act can promote a healthy climate and social relationship among the school community. For example, healthy school environment can provide teachers with happiness, and through the positive mood, students can learn with joy. L. Fried [42] highlighted that happiness is always displayed on the face of the teachers, which has a direct impact on the students during learning. So, we can argue that the feeling of happiness can encourage IB of teachers. Also, innovative and creative teachers can attract and stimulate students' minds by applying fun to the content of lessons during teaching.

\section{Organisational climate}

Organisational climate (OC) is sometimes used equally with work environment. OC plays a major role in the innovation of any business, as it has become critical for individuals, organisations and nations in a challenging world [43]. Therefore, organisational climate has been given much attention by numerous researchers [16]. OC emphasises the importance of employees' perception as to which extent the organisation encourages innovation. For example, practices to motivate inventions or new ideas, supportive procedure, awareness of the importance of innovation and achieving of results. According to [44], OC has a significant relationship with innovativeness and creativity of employees. Research shows that it is crucial for organisations to support and reward workers to encourage IB at workplace [3, $45,46]$. Thus, organisational supportiveness or climate encouraging innovativeness should include the following: rewarding employees for maintaining their innovativeness, providing learning opportunities to develop new ideas, tolerance for failures, empowerment and useful administrative practices to create suitable OC that fosters sustainable climate for innovation [43]. G. Solomon, E. Winslow, A. Tarabishy [47] and R. Imran, T. Saeed, M. Anis-ul-Haq, A. Fatima [43] conclude that to achieve work environment that supports innovation, it should have features like autonomy, encouragement by supervisor and team cohesion. Additionally, R. Shanker, R. Bhanugopan, van der Heijden, M. Farrell [16] identified that OC variables such as organisational support, management support, support by team member and challenging work have strong impact on individual innovation and creativity. So, to boost creativity and innovation of among the workforce, organisations should create a work environment with supportive features and reward strategy [48].

Thus, creative and innovative teaching depends on the employee's working conditions and OC [49]. T. Fidan, I. Oztürk [50] explain that a positive working environment, opportunities for learning, fairness and well treatment encourages teachers to develop new teaching methods, and which in turn, serve as a challenge in the education process for their students. Similarly, F. Hénard, D. Roseveare [51] confirm that features such as supportive school environment and good relationship with co-workers encourage teachers' innovative teaching. Consequently, a positive organisational climate perceive by teachers can encourage IB.

\section{Affective Commitment}

Organisational commitment (OC) has grown popularity in fields like industrial and organisational psychology [52]. J. Meyer, N. Allen [53] defined OC as a tri-dimensional concept namely: continuous, normative, and affective dimensions. However, among the three components mentioned above, affective commitment has the strongest connection with the meaning of attitude and employee outcome [54]. Innovation is risky process that involves behavioural aspect of an individual in dealing with a problem [55]. Thus, IB can only be practiced by employees that have positive feelings of attachment or identification with the organisation. M. Xerri, Y. Brunetto [56] assume that employees' affective commitment (AC) to the organisation will influence their ability to innovative, share knowledge tackle work-based issues. As a result, there are many literatures that examined the relationship between IB and AC [55, 57, 58, 59]. These scholars concluded that AC has strong connection with positive work outcomes, such as IB, happiness, satisfaction. Employees that are strongly committed or attached to their workplace are more likely to perform effectively and develop new ideas to help the organisation [56]. While some researchers $[60,61,62]$ found that AC eliminate negative impact of health problems and reduce work pressure of employees. 
L. Rhoades, R. Eisenberger, S. Armeli [63] describe AC as the employee's feeling of emotional bond or attachment to the workplace. Employees that are affectively committed are usually considered to be loyal and dedicated [64]. Also, sense of belonging is connected with the emotional attachment of the employees and these employees have the willingness to work effectively and to be engaged in productive activities towards the attainment of goals [65]. In summary, affectively committed employees are more concerned with the wellbeing of their workplace and are more motivated to support the organisation. This is because, such employees align their visions and with the organisation's visions [66]. For example, developing innovative solutions to problems, putting extra effort to acquire innovative capabilities and improving innovative behaviour to increase performance.

Therefore, from the perspective of bonding to schools, affective commitment refers to emotional affection of the teachers' involvement in work with feeling of pleasure and identification of with the schools [5]. Also, it can be described as the willingness of the teachers to maintain membership in their school as the responsibility for achieving goals [67]. The latter is in line with J. Meyer, N. Allen [53] opinion that AC is related to emotional relationship with subordinate, identification with and involvement members of the organisations. This implies that subordinates that have high level of AC will remain as members of the organisation because they are confident about the goals and values of the organisation [68].

\section{Transformational Leadership}

Innovation is never a solitary or lonely process [69]. IB is determined by the interaction with others, particularly depended on leaders to provide resources, information and support that are needed by employees to innovate [70]. The positive relationship between a leader and the employees is confirmed by numerous scholars such as $[71,72,73,74]$. The scholars supported that leaders are the driving force behind individual innovation. This implies that innovation stimulating leadership can encourage IB of employees. However, R. Basu, S. Green [75] argue that the relationship between a leader and IB of employees would only be strong if the employees perceive that their IB will benefit their work.
Therefore, among the different types of leadership styles, this paper selected Transformational leadership to demonstrate the positive effect of a leader to influence IB of individuals. Transformational Leadership (TFL) is the ability of the leader to inspire employees to have confidence and trust in performing at a higher level, making changes and working efficiently in the interest of the organisation [74]. TFL has components such as [76]:

(1) idealised influence - refers to leaders who are role model;

(2) inspirational motivation - involves leader's ability to encourage or motivate employee to work enthusiastically and positively;

(3) intellectual stimulation- means leader's ability to inspire the team to identify solutions to problems in different perspectives by using initiations and creativity;

(4) individualised consideration - refers to leader's ability to be concerned with employees' needs and desires by making them feel valued by the organisation.

According to J. de Jong, D. Hartog [77] leadership behaviours show features such as providing resources, consultation, delegating, monitoring and recognising task assignment that have substantial relationship with IB. B. Afsar, Y. Badir, B. Bin Saeed [78] and V. García-Morales, F. LlorénsMontes, A. Verdú-Jover [79] confirm that TFL affects organisational innovation and knowledge management. Also, a similar study by N. Nusair, R. Ababneh, Y. Kyung Bae [80] support that TFL affects both organisational innovation and learning orientation.

However, poorly prepared or inadequately positioned leaders may create enormous problems for any organisation [81]. Employees need leaders with competencies and skills in leading self, others, the organisation and systems [82]. L. Gumusluoğlu, A. Ilsev [83] found that some employees are not usually influenced by their leaders or supervisors, but rather external work contacts can influence their IB. People with more external contact are likely to perform higher levels of IB because they are exposed to different opportunities and can easily obtain support or resources to implement the new idea [84]. However, numerous empirical investigations have confirmed a significant relationship between leaders and employees [85, 86, 87]. 


\section{RESULTS AND DISCUSSION}

Evidence from the critical review of literature found that teachers play a role in promoting both academic and social success of educational institutes [88]. Job roles and performances of teachers in educational and social processes are important in providing school development [89]. Thus, enhancing teachers' performance can be confirmed through their innovative behaviours after recruitment. For instance, teachers who have innovative skills can ensure continuous performance and sustainability of in their professional development [90]. Revealing how $\mathrm{WH}, \mathrm{OC}$, AC and TFL influence IB is surely a great importance in terms of providing quality education through innovative teaching.

As a result, this paper proposes a relationship model of factors influencing IB that can be used to support teachers in secondary school (see Figure 1).

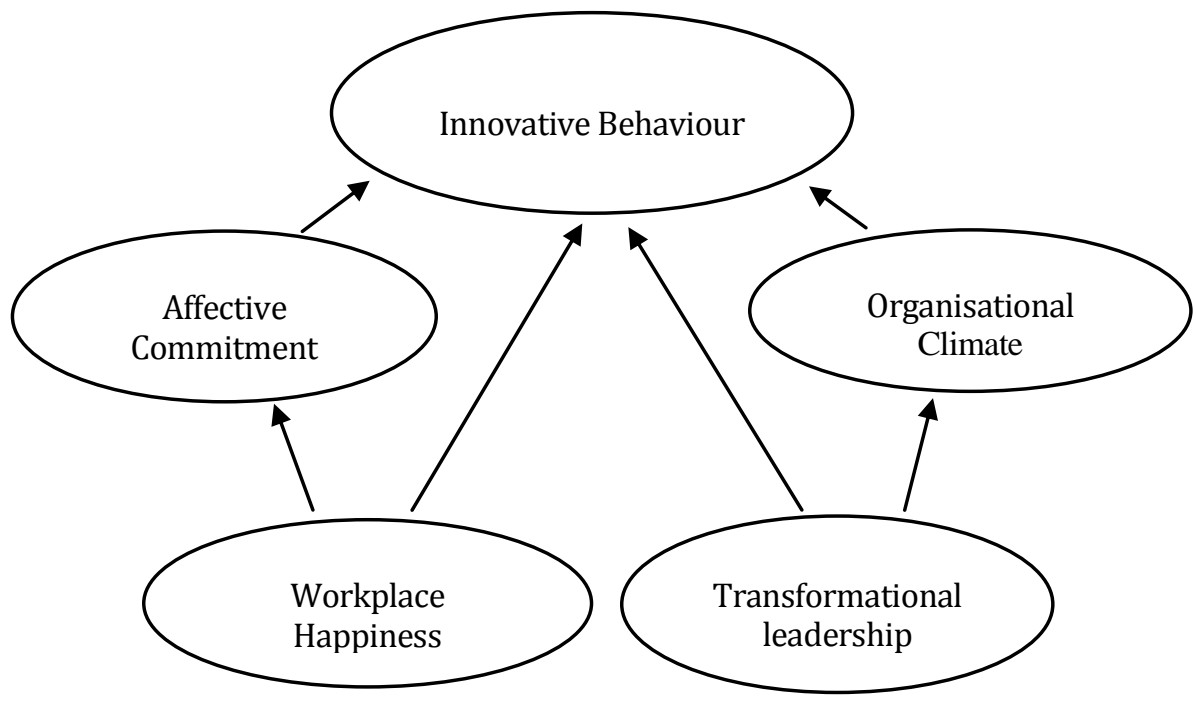

Figure 1 - Proposed model showing the relationship among factors influencing innovative behaviour of teachers in secondary schools

Figure 1 shows that workplace happiness, organisational climate, affective commitment and transformational leadership directly influence innovative behaviour. Meanwhile, workplace happiness affects affective commitment to innovative behaviour. Likewise, transformational leadership indirectly affects organisational climate to encourage innovative behaviour.

Accordingly, organisations should attempt to create and maintain WH to increase the level of $\mathrm{AC}$, as well as encourage continuous and normative commitment to maintain the desire to build IB among employees. According to M. Janik, S. Rothmann [91], happiness at workplace can improve individual performance of teachers as well as innovative behaviour. However, workplace happiness and affective commitment cannot be achieved without effective leadership style and positive organisational climate. In support, A. Salas-Vallina, Á. López-Cabrales, J. Alegre, R. Fernández [92] agree that effective leadership behaviour have a positive connection with happiness and job satisfaction. In fact, S. Meena,
M. Agarwal [93] believe that providing a conducive organisational climate can affect workplace happiness positively.

\section{CONCLUSION}

This paper aimed to develop a conceptual framework of factors influencing innovative behaviour of teachers in secondary schools. The model demonstrates relationship among workplace happiness $(\mathrm{WH})$, organisational climate (OC), affective commitment (AF) and transformational leadership (TFL). The proposed model can be used to assist future study on factors influencing teachers' innovative behaviour in schools, as the relationship between these factors can be examined. The knowledge acquired from the findings will add to the existing knowledge regarding innovative behaviour in Nigeria. Also, it can be used as a guideline to support teachers in developing innovative behaviour to improve effectiveness of the teaching profession and quality education. 


\section{REFERENCES}

1. Akiri, A. A., \& Ugborugbo, N. M. (2009). Teachers' Effectiveness and Students' Academic Performance in Public Secondary Schools in Delta State, Nigeria. Studies on Home and Community Science, 3(2), 107-113. doi: 10.1080/09737189.2009.11885284

2. Van der Heijden, H. R. M. A., Geldens, J. J. M., Beijaard, D., \& Popeijus, H. L. (2015). Characteristics of teachers as change agents. Teachers and Teaching, 21(6), 681-699. doi: $10.1080 / 13540602.2015 .1044328$

3. Hammond, M. M., Neff, N. L., Farr, J. L., Schwall, A. R., \& Zhao, X. (2011). Predictors of individual-level innovation at work: A meta-analysis. Psychology of Aesthetics, Creativity, and the Arts, 5(1), 90105. doi: $10.1037 / \mathrm{a} 0018556$

4. Kheng, Y., \& Mahmood, R. (2013). The relationship between pro-innovation organizational climate, leader-member exchange and innovative work behavior: A study among the knowledge workers of the knowledge intensive business services in Malaysia. Business Management Dynamics, 2(8), 15-30.

5. Abdullah, A., \& Ling, Y.-L. (2016). Understanding Workplace Happiness in Schools: The Relationships between Workplace Happiness, Teachers' Sense of Efficacy, Affective Commitment and Innovative Behavior. Academy of Social Science Journal, 1(4), 80-83.

6. Thurlings, M., Evers, A. T., \& Vermeulen, M. (2015). Toward a Model of Explaining Teachers' Innovative Behavior. Review of Educational Research, 85(3), 430-471. doi: 10.3102/0034654314557949

7. Messmann, G., \& Mulder, R. H. (2010). Innovative Work Behaviour in Vocational Colleges: Understanding How and Why Innovations Are Developed. Vocations and Learning, 4(1), 63-84. doi: $10.1007 /$ s12186-010-9049-y

8. De Jong, J. P., \& Hartog, D. (2008, November). Innovative work behavior: Measurement and validation. Retrieved from http://ondernemerschap.panteia.nl/pdf-ez/h200820.pdf

9. Binnewies, C., \& Gromer, M. (2012). Creativity and innovation at work: The role of work characteristics and personal initiative. Psicothema, 24(1), 100-105.

10. Naranjo-Valencia, J. C., Jiménez-Jiménez, D., \& Sanz-Valle, R. (2011). Innovation or imitation? The role of organizational culture. Management Decision, 49(1), 55-72. doi: 10.1108/00251741111094437

11. Gassmann, O., Enkel, E., \& Chesbrough, H. (2010). The future of open innovation. R\&D Management, 40(3), 213-221. doi: 10.1111/j.1467-9310.2010.00605.x

12. Baer, M. (2012). Putting creativity to work: The implementation of creative ideas in organizations. Retrieved from http://citeseerx.ist.psu.edu/viewdoc/download?doi=10.1.1.866.22\&rep=rep1\&type=pdf

13. Yuan, F., \& Woodman, R. (2010). Innovative behavior in the workplace: The role of performance and image outcome expectations. Academy of Management Journal, 53(2), 323-342.

14. Ma Prieto, I., \& Pilar Pérez-Santana, M. (2014). Managing innovative work behavior: the role of human resource practices. Personnel Review, 43(2), 184-208. doi: 10.1108/pr-11-2012-0199

15. Pukienè, A. (2016). Innovative work behavior - the role of human resource management and affective commitment (Master's thesis). Retrieved from http://gs.elaba.lt/object/elaba:18899278/18899278.pdf

16. Shanker, R., Bhanugopan, R., van der Heijden, B. I. J. M., \& Farrell, M. (2017). Organizational climate for innovation and organizational performance: The mediating effect of innovative work behavior. Journal of Vocational Behavior, 100, 67-77. doi: 10.1016/j.jvb.2017.02.004 
17. Chatchawan, R., Trichandhara, K., \& Rinthaisong, I. (2017). Factors Affecting Innovative Work Behavior of Employees in Local Administrative Organizations in the South of Thailand. International Journal of Social Sciences and Management, 4(3), 154. doi: 10.3126/ijssm.v4i3.17755

18. De Jong, J., \& den Hartog, D. (2010). Measuring Innovative Work Behaviour. Creativity and Innovation Management, 19(1), 23-36. doi: 10.1111/j.1467-8691.2010.00547.x

19. Janssen, 0. (2000). Job demands, perceptions of effort-reward fairness and innovative work behaviour. Journal of Occupational and Organizational Psychology, 73(3), 287-302. doi: 10.1348/096317900167038

20. Kontoghiorghes, C., Awbre, S. M., \& Feurig, P. L. (2005). Examining the relationship between learning organization characteristics and change adaptation, innovation, and organizational performance. Human Resource Development Quarterly, 16(2), 185-212. doi: 10.1002/hrdq.1133

21. Mishra, P., \& Koehler, M. (2006). Technological pedagogical content knowledge: A framework for teacher knowledge. Teachers College Record, 108(6), 1017-1054.

22. Scott, S. G., \& Bruce, R. A. (1994). Determinants of innovative behavior: a path model of individual innovation in the workplace. Academy of Management Journal, 37(3), 580-607. doi: $10.2307 / 256701$

23. Kivunja, C. (2015). Innovative Methodologies for 21st Century Learning, Teaching and Assessment: A Convenience Sampling Investigation into the Use of Social Media Technologies in Higher Education. International Journal of Higher Education, 4(2). doi: 10.5430/ijhe.v4n2p1

24. Buxton, M., Phillippi, J. C., \& Collins, M. R. (2014). Simulation: A New Approach to Teaching Ethics. Journal of Midwifery \& Women's Health, 60(1), 70-74. doi: 10.1111/jmwh.12185

25. Abdullah, A. G. K., Ling, Y.-L., \& Ping, C. S. (2017). Workplace Happiness, Transformational Leadership and Affective Commitment. Advanced Science Letters, 23(4), 2872-2875. doi: 10.1166/asl.2017.7588

26. Fisher, C. (2010). Happiness at work. International journal of management reviews, 12(4), 384-412.

27. Robertson, I., \& Cooper, C. (2011). Well-Being. doi: $10.1057 / 9780230306738$

28. Sousa, J. M. de, \& Porto, J. B. (2015). Happiness at Work: Organizational Values and PersonOrganization Fit Impact. Paidéia (Ribeirão Preto), 25(61), 211-220. doi: 10.1590/198243272561201509

29. Achor, S. (2011). The happiness advantage: The seven principles of positive psychology that fuel success and performance at work. London: Virgin.

30. Salas-Vallina, A., Alegre, J., \& Fernandez, R. (2017). Happiness at work and organisational citizenship behaviour. International Journal of Manpower, 38(3), 470-488. doi: 10.1108/ijm-102015-0163

31. Andujar, M., Nijholt, A., \& Gilbert, J. E. (2016). Designing a Humorous Workplace: Improving and Retaining Employee's Happiness. Advances in Affective and Pleasurable Design, 683-693. doi: 10.1007/978-3-319-41661-8_66

32. Kaya, A. (2015). The Relationship between Spiritual Leadership and Organizational Citizenship Behaviors: A Research on School Principals' Behaviors. Educational Sciences: Theory \& Practice, 15(3). doi: 10.12738/estp.2015.3.1988

33. Straume, L. V., \& Vittersø, J. (2012). Happiness, inspiration and the fully functioning person: Separating hedonic and eudaimonic well-being in the workplace. The Journal of Positive Psychology, 7(5), 387-398. doi: 10.1080/17439760.2012.711348

34. Csikszentmihalyi, M. (1997). Happiness and creativity. The Futurist, 31(5), 8-12.

35. Zaker, A., Dadsetan, A., Nasiri, Z., Azimi, S., \& Rahnama, F. (2016). Effectiveness of Happiness on Self-efficacy of Students. Electronic Journal of Biology, 12(4). 
36. Hills, P., \& Argyle, M. (2001). Emotional stability as a major dimension of happiness. Personality and Individual Differences, 31(8), 1357-1364. doi: 10.1016/s0191-8869(00)00229-4

37. Wang, S., Yi, X. (2011). It's happiness that counts: Full mediating effect of job satisfaction on the linkage from LMX to turnover intention in Chinese companies. International Journal of Leadership Studies, 6(3), 337-356.

38. Tee, E., Ashkanasy, N. M., \& Paulsen, N. (2013). The influence of follower mood on leader mood and task performance: An affective, follower-centric perspective of leadership. The Leadership Quarterly, 24(4), 496-515. doi: 10.1016/j.leaqua.2013.03.005

39. Visser, V. A., van Knippenberg, D., van Kleef, G. A., \& Wisse, B. (2013). How leader displays of happiness and sadness influence follower performance: Emotional contagion and creative versus analytical performance. The Leadership Quarterly, 24(1), 172-188. doi: 10.1016/j.leaqua.2012.09.003

40. Becker, E., Goetz, T., Morger, V., \& Ranellucci, J. (2014). The importance of teachers' emotions and instructional behavior for their students' emotions - An experience sampling analysis. Teaching and Teacher Education, 43, 15-26. doi: 10.1016/j.tate.2014.05.002

41. Garner, P. W. (2010). Emotional Competence and its Influences on Teaching and Learning. Educational Psychology Review, 22(3), 297-321. doi: 10.1007/s10648-010-9129-4

42. Fried, L. (2011). Teaching Teachers about Emotion Regulation in the Classroom. Australian Journal of Teacher Education, 36(3). doi: 10.14221/ajte.2011v36n3.1

43. Imran, R., Saeed, T., Anis-ul-Haq, M., Fatima, A. (2010). Organizational climate as a predictor of innovative work behavior. African Journal of Business Management, 4(15), 3337-3343.

44. Dul, J., Ceylan, C. (2014). The Impact of a Creativity-supporting Work Environment on a Firm's Product Innovation Performance. Journal of Product Innovation Management, 31, 1254-1267. doi: 10.1111/jpim.12149

45. Yu, C., Yu, T.-F., \& Yu, C.-C. (2013). Knowledge Sharing, Organizational Climate, and Innovative Behavior: A Cross-Level Analysis of Effects. Social Behavior and Personality: An International Journal, 41(1), 143-156. doi: 10.2224/sbp.2013.41.1.143

46. Chen, C., Huang, J., \& Hsiao, Y. (2010). Knowledge management and innovativeness. International Journal of Manpower, 31(8), 848-870. doi: 10.1108/01437721011088548

47. Solomon, G., Winslow, E., \& Tarabishy, A. (1998). The role of climate in fostering innovative behavior in entrepreneurial SMEs. Retrieved from http://citeseerx.ist.psu.edu/viewdoc/download?doi=10.1.1.629.5933\&rep=rep1\&type=pdf

48. Noor, H. M., \& Dzulkifli, B. (2013). Assessing Leadership Practices, Organizational Climate and Its Effect towards Innovative Work Behaviour in R\&D. International Journal of Social Science and Humanity, 3(2), 129-133. doi: 10.7763/ijssh.2013.v3.211

49. Rinkevich, J. L. (2011). Creative Teaching: Why it Matters and Where to Begin. The Clearing House: A Journal of Educational Strategies, Issues and Ideas, 84(5), 219-223. doi: 10.1080/00098655.2011.575416

50. Fidan, T., \& Oztürk, I. (2015). The Relationship of the Creativity of Public and Private School Teachers to their Intrinsic Motivation and the School Climate for Innovation. Procedia - Social and Behavioral Sciences, 195, 905-914. doi: 10.1016/j.sbspro.2015.06.370

51. Hénard, F., Roseveare, D. (2012, September). Fostering quality teaching in higher education: Policies and Practices. Retrieved from http://www.oecd.org/education/imhe/QT\%20policies\%20and\%20practices.pdf

52. Cohen, A. (2007). Commitment before and after: An evaluation and reconceptualization of organizational commitment. Human Resource Management Review, 17(3), 336-354. doi: 10.1016/j.hrmr.2007.05.001 
53. Meyer, J. P., \& Allen, N. J. (1991). A three-component conceptualization of organizational commitment. Human Resource Management Review, 1(1), 61-89. doi: 10.1016/10534822(91)90011-z

54. Vandenberghe, C., Bentein, K., \& Stinglhamber, F. (2004). Affective commitment to the organization, supervisor, and work group: Antecedents and outcomes. Journal of Vocational Behavior, 64(1), 47-71. doi: 10.1016/s0001-8791(03)00029-0

55. Jafri, M. (2010). Organizational commitment and employee's innovative behavior. Journal of Management Research, 10(1), 62-68.

56. Xerri, M. J., \& Brunetto, Y. (2013). Fostering innovative behaviour: the importance of employee commitment and organisational citizenship behaviour. The International Journal of Human Resource Management, 24(16), 3163-3177. doi: 10.1080/09585192.2013.775033

57. Camelo-Ordaz, C., García-Cruz, J., Sousa-Ginel, E., \& Valle-Cabrera, R. (2011). The influence of human resource management on knowledge sharing and innovation in Spain: the mediating role of affective commitment. The International Journal of Human Resource Management, 22(7), 14421463. doi: 10.1080/09585192.2011.561960

58. Noori, R., Alias, M., \& Rosdi, I. (2017). Understanding the Drivers for Innovative Work Behavior in Malaysian SMEs. Retrieved from http://docplayer.net/50753775-Proceedings-of-the-5thinternational-conference-on-innovation-and-entrepreneurship-icie-2017.html

59. Hoi, S. B., Cundiff, N., Kim, K., \& Akhatib, S. N. (2018). The effect of work-family conflict and job insecurity on innovative behaviour of Korean workers: the mediating role of organisational commitment and job satisfaction. International Journal of Innovation Management, 22(01), 1850003. doi: 10.1142/s1363919618500032

60. Schmidt, K.-H. (2007). Organizational commitment: A further moderator in the relationship between work stress and strain? International Journal of Stress Management, 14(1), 26-40. doi: 10.1037/1072-5245.14.1.26

61. Glazer, S., \& Kruse, B. (2008). The role of organizational commitment in occupational stress models. International Journal of Stress Management, 15(4), 329-344. doi: 10.1037/a0013135

62. Pignata, S., \& Winefield, A. H. (2013). Stress-reduction Interventions in an Australian University: A Case Study. Stress and Health, 31(1), 24-34. doi: 10.1002/smi.2517

63. Rhoades, L., Eisenberger, R., \& Armeli, S. (2001). Affective commitment to the organization: The contribution of perceived organizational support. Journal of Applied Psychology, 86(5), 825-836. doi: 10.1037/0021-9010.86.5.825

64. Iqbal, A., Tufail, M., \& Lodhi, R. (2015). Employee loyalty and organizational commitment in Pakistani organizations. Global Journal of Human Resource Management, 3(1), 1-11.

65. Casimir, G., Ngee Keith Ng, Y., Yuan Wang, K., \& Ooi, G. (2014). The relationships amongst leadermember exchange, perceived organizational support, affective commitment, and in-role performance. Leadership \& Organization Development Journal, 35(5), 366-385. doi: 10.1108/lodj-04-2012-0054

66. Ng, T. W. H. (2015). The incremental validity of organizational commitment, organizational trust, and organizational identification. Journal of Vocational Behavior, 88, 154-163. doi: 10.1016/j.jvb.2015.03.003

67. Li, Y. (2014). Building affective commitment to organization among Chinese university teachers: the roles of organizational justice and job burnout. Educational Assessment, Evaluation and Accountability, 26(2), 135-152. doi: 10.1007/s11092-014-9192-3

68. Mousa, M., \& Alas, R. (2016). Cultural Diversity and Organizational Commitment: A Study on Teachers of Primary Public Schools in Menoufia (Egypt). International Business Research, 9(7), 154. doi: 10.5539/ibr.v9n7p154 
69. Ramamoorthy, N., Flood, P. C., Slattery, T., \& Sardessai, R. (2005). Determinants of Innovative Work Behaviour: Development and Test of an Integrated Model. Creativity and Innovation Management, 14(2), 142-150. doi: 10.1111/j.1467-8691.2005.00334.x

70. Sanders, K., Moorkamp, M., Torka, N., Groeneveld, S., \& Groeneveld, C. (2010). How to Support Innovative Behaviour?The Role of LMX and Satisfaction with HR Practices. Technology and Investment, 01(01), 59-68. doi: 10.4236/ti.2010.11007

71. Masood, M., \& Afsar, B. (2017). Transformational leadership and innovative work behavior among nursing staff. Nursing Inquiry, 24(4), e12188. doi: 10.1111/nin.12188

72. Abbas, G., Iqbal, J., Waheed, A., \& Naveed Riaz, M. (2012). Relationship between transformational leadership style and innovative work behavior in educational institutions. Journal of Behavioural Sciences, 22(3), 18-32.

73. Krause, D. E. (2004). Influence-based leadership as a determinant of the inclination to innovate and of innovation-related behaviors. The Leadership Quarterly, 15(1), 79-102. doi: 10.1016/j.leaqua.2003.12.006

74. Choi, S. B., Kim, K., Ullah, S. M. E., \& Kang, S.-W. (2016). How transformational leadership facilitates innovative behavior of Korean workers. Personnel Review, 45(3), 459-479. doi: 10.1108/pr-032014-0058

75. Basu, R., \& Green, S. G. (1997). Leader-Member Exchange and Transformational Leadership: An Empirical Examination of Innovative Behaviors in Leader-Member Dyads. Journal of Applied Social Psychology, 27(6), 477-499. doi: 10.1111/j.1559-1816.1997.tb00643.x

76. Khan, M., Aslam, N., \& Riaz, M. (2012). Leadership Styles as Predictors of Innovative Work Behavior. Pakistan Journal of Social \& Clinical Psychology, 9(2), 17-22.

77. de Jong, J. \& Hartog, D. (2007). How leaders influence employees' innovative behaviour. European Journal of Innovation Management, 10(1), 41-64. doi: 10.1108/14601060710720546

78. Afsar, B., F. Badir, Y., \& Bin Saeed, B. (2014). Transformational leadership and innovative work behavior. Industrial Management \& Data Systems, 114(8), 1270-1300. doi: 10.1108/imds-052014-0152

79. García-Morales, V. J., Lloréns-Montes, F. J., \& Verdú-Jover, A. J. (2008). The Effects of Transformational Leadership on Organizational Performance through Knowledge and Innovation. British Journal of Management, 19(4), 299-319. doi: 10.1111/j.14678551.2007.00547.x

80. Nusair, N., Ababneh, R., \& Kyung Bae, Y. (2012). The impact of transformational leadership style on innovation as perceived by public employees in Jordan. International Journal of Commerce and Management, 22(3), 182-201. doi: 10.1108/10569211211260283

81. Khan, R., Rehman, A., \& Fatima, A. (2009). Transformational leadership and organizational innovation: Moderated by organizational size. African Journal of Business Management, 3(11), 678-684.

82. Moss, S. A., \& Ritossa, D. A. (2007). The Impact of Goal Orientation on the Association between Leadership Style and Follower Performance, Creativity and Work Attitudes. Leadership, 3(4), 433-456. doi: $10.1177 / 1742715007082966$

83. Gumusluoğlu, L., \& Ilsev, A. (2009). Transformational Leadership and Organizational Innovation: The Roles of Internal and External Support for Innovation. Journal of Product Innovation Management, 26(3), 264-277. doi: 10.1111/j.1540-5885.2009.00657.x

84. Perry-Smith, J. E., \& Shalley, C. E. (2003). The Social Side of Creativity: A Static and Dynamic Social Network Perspective. The Academy of Management Review, 28(1), 89-106. doi: $10.2307 / 30040691$ 
85. Lee, J. (2008). Effects of leadership and leader-member exchange on innovativeness. Journal of Managerial Psychology, 23(6), 670-687. doi: 10.1108/02683940810894747

86. Akram, T., Lei, S., \& Haider, M. J. (2016). The impact of relational leadership on employee innovative work behavior in IT industry of China. Arab Economic and Business Journal, 11(2), 153-161. doi: 10.1016/j.aebj.2016.06.001

87. Torres, F. C., Espinosa, J. C., Dornberger, U., \& Acosta, Y. A. C. (2017). Leadership and Employees' Innovative Work Behavior: Test of a Mediation and Moderation Model. Asian Social Science, 13(9), 9. doi: 10.5539/ass.v13n9p9

88. Dimkpa, D. (2015). Teachers' Conduct in the 21st Century: The Need for Enhancing Students' Academic Performance. Journal of Education and Practice, 6(35), 71-78.

89. Caprara, G., Barbaranellia, C., Steca, P., \& Malone, P. (2006). Teachers' self-efficacy beliefs as determinants of job satisfaction and students' academic achievement: A study at the school level. Journal of school psychology, 44(6), 473-490. doi: 10.1016/j.jsp.2006.09.001

90. Bakkenes, I., Vermunt, J. D., \& Wubbels, T. (2010). Teacher learning in the context of educational innovation: Learning activities and learning outcomes of experienced teachers. Learning and Instruction, 20(6), 533-548. doi: 10.1016/j.learninstruc.2009.09.001

91. Janik, M., \& Rothmann, S. (2015). Meaningful work and secondary school teachers' intention to leave. South African Journal of Education, 35(2), 1-13. doi: 10.15700/saje.v35n2a1008

92. Salas-Vallina, A., López-Cabrales, Á., Alegre, J., \& Fernández, R. (2017). On the road to happiness at work (HAW). Personnel Review, 46(2), 314-338. doi: 10.1108/pr-06-2015-0186

93. Meena, S., \& Agarwal, M. (2014). The Relationship among Organisational Climate, Job Satisfaction and Happiness of the Employees of Educational Institutions. American International Journal of Research in Humanities, Arts and Social Sciences, 6(2), 149-152. 